\title{
Common mental disorders and associated factors among final-year healthcare students
}

\author{
Edméa Fontes de Oliva Costa ${ }^{1 *}$, Margleice Marinho Vieira Rocha², Ana Teresa Rodrigues de Abreu Santos ${ }^{3}$, \\ Enaldo Vieira de Melo ${ }^{4}$, Luiz Antonio Nogueira Martins ${ }^{5}$, Tarcisio Matos Andrade ${ }^{6}$ \\ ${ }^{1}$ Adjunt Professor of Psychiatry, Department of Medicine; Federal University of Sergipe (DME/UFS); Dotorate in PPGMS/UFBA \\ ${ }^{2}$ Graduate in Medicine (DME/UFS): Masters student, professional in Neurology of University of São Paulo of Ribeirão Preto (USP-RP) \\ ${ }^{3}$ Medical Coordinator of Mental Health Juvenile Service of the teaching Hospital and the Psycho Pedagogic assistence service to medical students of the UFBA; Masters in PPGMS/UFBA \\ ${ }^{4}$ Assistent professor at the department of medicine at the Federal University of Sergipe (UFS) \\ ${ }^{5}$ Associate professor of psychiatry at the Federal University of São Paulo (UNIFESP) \\ ${ }^{6}$ Associate professor of the Faculty of Medicine of Bahia and supervisor of the first and third authors in the postgraduate program in health and medicine at the Federal University of Bahia (PPGMS/UFBA)
}

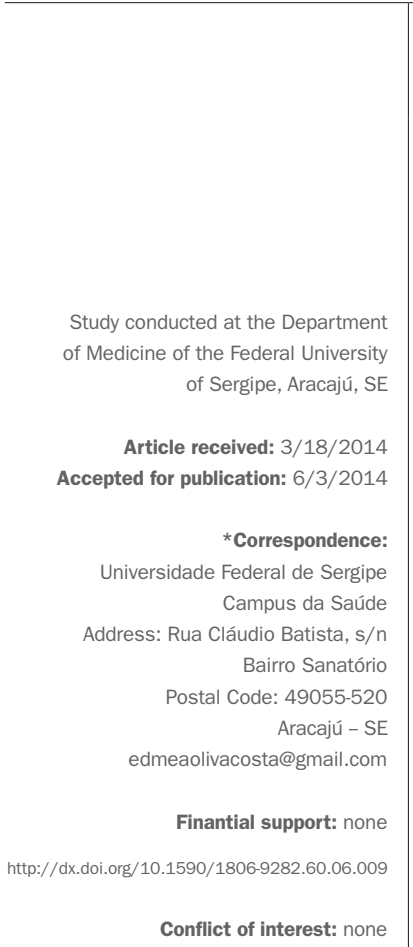

\section{SUMMARY}

Objective: to assess the prevalence of common mental disorder (CMD) and to identify potential associated factors among medical, dental and nursing students. Method: a cross-sectional study conducted in a public university in Northeast Brazil with 172 undergraduate students of the last three semesters of the medicine, dentistry and nursing courses, in February 2010, using the Self Reporting Questionnaire (SRQ-20) and a structured questionnaire developed by the authors. Logistic regression was performed for data analysis.

Result: the prevalence of CMD was 33.7\%. The courses presented no differences in CMD prevalence. The logistic regression analysis showed a strong association of the following variables with $\mathrm{CMD}$ : female ( $\mathrm{OR}=4.34)$, lack of good expectations regarding the future $(\mathrm{OR}=5.83)$, course as not a source of pleasure $(\mathrm{OR}=7.52)$ and feeling emotionally tense $(\mathrm{OR}=11.23)$.

Conclusion: the high prevalence suggests that immediate preventive measures should be implemented, such as the setting up of psycho-pedagogic support services for students, and teacher development programs.

Keywords: mental health, mental disorders, students, dental, students, medical students, nursing, occupational health.

\section{INTRODUCTION}

Common mental disorders (anxiety, depressive and somatoform disorders), also known as minor psychiatric disorders, are mild psychic troubles that, throughout the years, may cause great biopsychic and social impact. ${ }^{1}$ These disorders have symptoms such as: fatigue, insomnia, forgetfulness, difficulty in concentrating, irritability and somatic complaints. ${ }^{2}$ They also indicate relevant psychic suffering and may lead to the development of more serious mental disorders, which seems particularly important in the case of healthcare professionals for their role in assisting the population..$^{3-5}$

Medicine, dentistry and nursing are traditionally recognized as being some of the most strenuous courses at university level as they demand great physical, intellectual and emotional effort from students. In the last year of the undergraduate program, emotional exhaustion becomes more evident and ends up predisposing the students to common mental disorder. ${ }^{3,6-11}$

We know from the literature that the prevalence of common mental disorder in industrialized countries ranges from 7 to $30 \%{ }^{4}$ Similar studies drawn from the Brazilian population, showed that this prevalence varied from 22 to $35 \%{ }^{12,13}$

At the same university, a recent study including only medical students revealed a high prevalence of common mental disorder (42.5\%). ${ }^{14}$ To date, in this institution, there are no published researches on the mental health of nursing and dental students. National and international studies assessing this kind of population are also scarce. 
Several studies have showed that institutions responsible for the training of health professionals should take cognizance of their students' weaknesses regarding the educational process. ${ }^{15-18}$

This study aims to assess the prevalence of common mental disorder among the students of the last three semesters of the medicine, dentistry and nursing courses in a public university in Northeast Brazil and to identify the potential factors associated with this disorder.

\section{Methods}

The authors conducted a cross-sectional study in February 2010, in a public university from Northeast Brazil. The number of students per class when they were admitted into the university was: 40 for medicine, 20 for dentistry and 20 for the nursing course.

The medicine course follows the Brazilian traditional model for medical teaching comprised of 12 semesters: Basic Sciences Cycle ( $1^{\text {st }}$ to $4^{\text {th }}$ ), Preparatory Clinical Cycle ( $5^{\text {th }}$ to $\left.9^{\text {th }}\right)$, and Internship (10 ${ }^{\text {th }}$ to $\left.12^{\text {th }}\right)$.

The dentistry course presents 10 semesters: Basic Sciences Cycle ( $1^{\text {st }}$ to $\left.4^{\text {th }}\right)$, Preparatory Clinical Cycle ( $5^{\text {th }}$ to $\left.10^{\mathrm{th}}\right)$ and the Supervised Training Cycle ( $9^{\underline{\mathrm{th}}}$ and $\left.10^{\mathrm{th}}\right)$.

The Nursing course includes 9 semesters: Basic Sciences Cycle ( $1^{\text {st }}$ to $\left.4^{\text {th }}\right)$, Preparatory Clinical Cycle ( $5^{\frac{\text { th }}{h}}$ to $\left.8^{\text {th }}\right)$ and the Supervised Training Cycle (9 $9^{\text {th }}$ semester).

All the 220 students of medicine, dentistry and nursing regularly enrolled in the last three semesters of college at the time of this survey were invited to participate, and 175 accepted the research terms.

Participants were required to answer two self-administered questionnaires in the classrooms: the Self Reporting Questionnaire (SRQ-20) ${ }^{1}$ and a specific questionnaire developed by the authors.

Before that, the teaching staff in each of the three courses received letters from the researchers informing that a survey would be carried out, and asking their permission to have the questionnaires applied during class time.

Every classroom was approached at least twice in order to get the maximum adhesion of the students to the survey. Students who did not return their questionnaires were considered missing.

The SRQ-20 is an assessment scale of anxious, depressive and somatoform symptoms developed by the World Health Organization (WHO). It was introduced by Harding, in 1980, for screening minor psychiatric disorders in basic attention and was validated in Brazil by Mari. ${ }^{1,4}$ It is a self-administered instrument with 20 binary response questions related to psycho-emotional symptoms, which showed satisfactory indexes in the studies conducted by
Mari, with sensibility and specificity equal to 85 and $80 \%$, respectively. ${ }^{1}$ The students answered the questionnaire based on what they felt during the last 30 days. Scores higher or equal to 6 for men and higher or equal to 8 for women are considered as probable cases. This cutoff, according to the SRQ-20, was determined based on several studies. ${ }^{1,8,14}$ Although, this score does not implicate in formal diagnosis, it indicates relevant psychic suffering that draws attention to the mental health of healthcare professionals.

The structured self-administered questionnaire developed and tested by the authors in an earlier pilot study consisted of 54 questions related to socio-demographic features, educational process and personal aspects.

The data analysis was performed using the SPSS statistics software version 16.0. The analysis was done in three stages:

$1^{\text {st }}$ Population description through descriptive statistics (inferential statistics is not suitable for this study, since the authors studied the population instead of a random sample);

$2^{\text {nd }}$ Bivariate and simple analysis, including the construction of tables and calculation of crude odds ratio (OR) instead of prevalence ratio (PR) since OR is the measure obtained in the logistic regression (final step of our analysis) and can also be used in this type of study;

$3^{\text {rd }}$ Analysis of multiple variables by logistic regression. The variables' selection criteria are based on the variable's importance in the literature, on the authors' experience, and on the magnitude of the OR. The variables showing association with $\mathrm{CMD}>30 \%$ were kept in the final model.

The outcome variable (common mental disorder) was adjusted to the following predictive variables: sex, having a steady partner, religion, income, having another occupation, course (socio-demographic features); satisfaction with the course choice, attitude toward the course, thoughts about dropping out the course, self-assessment of academic performance, self-assessment of skill acquisition needed to become a good professional, satisfaction with the teaching strategies, attitude toward the course's activities, course as a source of pleasure (educational process); presence of physical disease, presence of mental disease, feeling emotionally stressed, reaction to conflicts, leisure time, emotional support, expectations about the future and feeling of happiness (personal aspects).

This study was approved by our institutional Ethics Committee of Research on Humans Beings (0018.0.107.00006 protocol number). Study participants signed a confidentiality agreement authorizing disclosure of data but 
concealing identity throughout the study period, including during the completion of questionnaires.

\section{RESULTS}

From all the 220 students enrolled in the last three semesters of the courses, 175 (79.5\%) took part in the research: medicine (113), dentistry (47) and nursing (60). Three participants did not answer the SRQ-20, thus being excluded from the study.

According to the cutoff point pre-established for male and female, the studied common mental disorder presented a general prevalence of $33.7 \%$ (Table 1).

\begin{tabular}{|c|c|c|c|c|}
\hline Variables & $N$ & $\%$ & $\mathrm{CMD}(\%)$ & Crude OR \\
\hline Total & 172 & 100 & 33.7 & \\
\hline \multicolumn{5}{|l|}{ Sex } \\
\hline Female & 108 & 62.8 & 43.5 & 3.71 \\
\hline Male & 64 & 37.2 & 17.2 & 1 \\
\hline \multicolumn{5}{|c|}{ Steady partner } \\
\hline Yes & 117 & 70.5 & 35.9 & 1.27 \\
\hline No & 49 & 29.5 & 30.6 & 1 \\
\hline Missing & 6 & & & \\
\hline \multicolumn{5}{|l|}{ Religion } \\
\hline Yes & 126 & 73.3 & 33.3 & 1 \\
\hline No & 46 & 26.7 & 34.8 & 1.06 \\
\hline \multicolumn{5}{|c|}{$\begin{array}{l}\text { Family income } \\
\text { (Minimum wage) }\end{array}$} \\
\hline 1 to 5 & 12 & 7.9 & 41.7 & 1.87 \\
\hline 6 to 10 & 54 & 35.5 & 42.6 & 1.95 \\
\hline 11 to 15 & 38 & 25 & 28.9 & 1.07 \\
\hline 16 to 20 & 19 & 12.5 & 31.6 & 1.21 \\
\hline More than 20 & 29 & 19.1 & 27.6 & 1 \\
\hline Missing & 20 & & & \\
\hline \multicolumn{5}{|c|}{ Have other occupation } \\
\hline Yes & 27 & 15.7 & 40.7 & 1.43 \\
\hline No & 145 & 84.3 & 32.4 & 1 \\
\hline
\end{tabular}

The studied population comprised predominantly female $(62.8 \%)$ and young (average age $23.5 \pm 1.6)$ students. The majority $(70.5 \%)$ had a steady partner, $73.3 \%$ practiced a religion, and $90.5 \%$ lived with relatives.

The majority (84.3\%) did not have any other occupation apart from being a student in that course, and most of them $(35.5 \%)$ had a family income of 6 to 10 minimum wages (Table 1).
Concerning variables related to the educational process, $77.6 \%$ of the students considered the course to be a source of pleasure, and $79.1 \%$ believed that their academic performance was good or excellent. Although 87.7\% thought that they were acquiring the skills necessary to become good professionals, only $29.3 \%$ were satisfied with the teaching strategies used. In total, $94.7 \%$ of the students were satisfied with their career choices, but $35.1 \%$ were uncomfortable with course activities and more than a half (56.4\%) had thought of dropping out the course at least once.

With regards to personal issues, around half of the students dedicated less than 6 hours per week to leisure activities (50\%), reacted aggressively or retracted themselves in situations of conflict (51.5\%), and considered themselves emotionally stressed (44.4\%).

In terms of a personal support network, $80.2 \%$ reported that they were receiving the emotional support they needed, $82 \%$ had good expectations for the future, and $92.4 \%$ reported feeling happy.

On bivariate analysis of variables related to the educational process, those students that had already thought of dropping out the course $(\mathrm{OR}=2.52)$ or felt uncomfortable in academic activities $(\mathrm{OR}=3.33)$ presented a greater association with the development of common mental disorders.

Concerning personal aspects, the probability of developing a common mental disorder was higher among the students who considered themselves emotionally stressed $(\mathrm{OR}=10.60)$, who reacted to conflicts in a retracted or aggressive way $(\mathrm{OR}=2.89)$, who referred the presence of physical disease $(\mathrm{OR}=3.21)$, or mental disorder diagnosed by a psychiatrist ( $\mathrm{OR}=2.73)$.

The probability of developing CMD increased among the students who reported absence of suitable emotional support ( $\mathrm{OR}=2.82)$, feeling unhappy $(\mathrm{OR}=13.11)$, and not so good expectations for the future $(\mathrm{OR}=8.71)$.

There were no significant statistical differences in the prevalence of CMD among students of medicine (30.1\%), dentistry (36.8\%) and nursing (39\%) (Table 2).

TABLE 2 Distribution of health care students according to course and prevalence of common mental disorder; Public University, Northeast, Brazil, 2010

\begin{tabular}{l|l|l|l} 
Variables & $\mathbf{n}$ & $\mathbf{C M D ( \% )}$ & Crude OR \\
\hline Total & 172 & 33.7 & \\
\hline Course & & & \\
\hline Medicine & 93 & 30.1 & 1 \\
\hline Dentistry & 38 & 36.8 & 1.35 \\
\hline Nursing & 41 & 39 & 1.49 \\
\hline
\end{tabular}


After adjustment using multiple logistic regression analysis, the following variables were associated with common mental disorder: female sex, not having good expectations for the future, not seeing the course as a source of pleasure and considering oneself emotionally tense (Table 3).

\begin{tabular}{|c|c|c|}
\hline Variables & Crude OR & Adjusted OR \\
\hline Total & 170 & \\
\hline \multicolumn{3}{|l|}{ Sex } \\
\hline Female & 3.71 & 4.34 \\
\hline Male & 1 & \\
\hline \multicolumn{3}{|c|}{$\begin{array}{l}\text { How do you consider yourself } \\
\text { emotionally? }\end{array}$} \\
\hline Calm & 1 & \\
\hline Tense & 10.61 & 11.23 \\
\hline \multicolumn{3}{|c|}{ Course as a source of pleasure } \\
\hline Yes & 1 & \\
\hline No & 2.07 & 7.52 \\
\hline \multicolumn{3}{|c|}{ Expectations for the future } \\
\hline Good & 1 & \\
\hline Not so good & 8.71 & 5.83 \\
\hline
\end{tabular}

\section{Discussion}

The general prevalence of common mental disorder among the students was higher than the rates found in general populations studied in industrialized countries. ${ }^{4}$

A survey carried out in Campinas, Brazil, using SQR20 , revealed a common mental disorder prevalence of $17 \%$ in the urban population. ${ }^{19}$ In Olinda, Brazil, a study using the same instrument revealed a 35\% CMD rate among individuals aged 15 years or older. ${ }^{13}$

A study at the Pernambuco University-Brazil (UPE) among students of some health care courses found a general prevalence of CMD of $34.1 \%$. The prevalence by course was: physical education (25\%), nursing (31.8\%), dentistry (33.3\%), and medicine (42.6\%). ${ }^{8}$ These results were similar to those found in our survey. Nevertheless, after comparing only medicine courses in Brazil, we found that the prevalence of CMD in students of the course surveyed (30.1\%) was smaller than the results of another earlier study by the author in the same university $(42.5 \%)$ than those found at UPE (42.6\%) and UNESP Botucatu (44.7\%) $)^{8,14,19}$ but similar to those found at the Bahia Federal University (29.6\%) and Santa Maria-Rio Grande do Sul University $(31.7 \%) .{ }^{20,21}$ We believe that similarities or differences in the courses' infra-structure and the educational models adopted contributed to these results.

Four variables that showed strong association with common mental disorder were identified after adjustment by multiple logistic regression analysis.

In the international literature, having low income, being female, not having a steady partner, being unemployed and practicing no religion are socio-demographic variables that may be identified as factors associated with common mental disorder. ${ }^{13,22,23}$

In this study, only females showed a strong association with common mental disorder after logistic regression. This finding coincides with the literature that asserts that women have higher prevalence of mental disorders and that CMD is the third health problem among females in developed countries and the fifth in undeveloped countries. ${ }^{13,24}$

Studies performed with others university students corroborate with these data. In medical schools in Tehran, female students were likely to develop psychic suffering in the same way that those who had very precarious financial conditions. ${ }^{25}$ On the other hand, in Turkey, a high association with depression among female and older students is seen. ${ }^{26}$

In other studies, CMD are more diagnosed in females because they look for health services more than males. ${ }^{22,24}$ In our study, the female sex variable showed strong association with CMD after logistic regression, but the female frequency was also greater than male.

Other variables in our study that demonstrated strong association with CMD were: 'not having good expectations for the future', 'not seeing the course as a source of pleasure' and 'feeling emotionally stressed'. This may be explained by the inherent features of the academic atmosphere including tests and tight deadlines that are mainly sources of stress for the students. This finding coincides with the literature which points out emotional stress as an important associated factor to common mental disorder. ${ }^{15,17,27}$

The healthcare courses present certain peculiarities in the educational process that impact negatively the student's physical and psychological health, cognitive function and learning. These stressful factors include the proximity of death and innumerous pathological processes, excessive workload, competitiveness, fear of making mistakes, late financial independence and disappointment with the course, as well as privation of the family conviviality and leisure. ${ }^{18,23,28,29}$ Sleep problems have been associated with deficits in attention and academic performance, 
drowsiness during classes, risk-taking behavior and depression, impaired social relationships, and poorer health..$^{30-32}$

Frequency of experiencing chronic illness, depression, anxiety disorder, seasonal affective disorder, mononucleosis, and sleep difficulties were significant stress predictors. ${ }^{31-33}$ Students of medicine, dentistry and nursing represent a population with high educational level that is constantly exposed to this inhospitable environment, which may predispose them to a higher risk of developing common mental disorder. ${ }^{9,14,16}$

Due to the workload of study and training that these courses require, students are also more inclined to develop burnout syndrome. . $32,34-36^{-36}$

Despite the high prevalence of CMD among the students assessed, only a small percentage (10.5\%) had any mental trouble diagnosed by a psychiatrist. In the same way, in a universe of 7,357 students from 36 medical schools of South Korea, 689 students presented depression and, out of these, only $9.7 \%$ were diagnosed and submitted to psychiatric treatment. ${ }^{37}$

This situation of under diagnosis may be motivated by the lack of a support service to the mental health of students in the universities.

Even the students of medicine, dentistry and nursing courses that studied with the most recognized health teams from the best universities in Brazil had their mental health very neglected by these institutions since no healthcare and psycho-pedagogical support service was made offered to the students. ${ }^{5}$ Many medical schools, especially in South and Southeast Brazil, have established psycho-pedagogical support services in the last years; however, in Northeast Brazil, this hasn't occurred in the same proportion. ${ }^{28}$

In the USA, most colleges and universities have now developed mental health and counseling programs commensurate with the size of their student bodies, although yet in 1957 the American College Health Association formed a Mental Health Section to serve mental health professionals, 37 years after the American Student Health Associations annual meeting in 1920 had identified "mental hygiene" as critical for college campuses to assist students to reach their highest potential. Indeed, the first student health service is credit to Amherst College in 1861.38

Regarding the issues of the educational process, we can observe that, although most students feel satisfied with their course choices and feel comfortable with their courses' activities, more than half of them is not satisfied with the teaching strategy and at least once considered to drop out the course. Nevertheless, these variables did not maintain a strong association with $\mathrm{CMD}$ after logistic regression.
The cross-sectional design of our study has a limitation, which is the simultaneous analysis of both exposure and outcome, preventing us from establishing causal relations among the associations found. On the other hand, the purpose of this study was restricted to assess the answers given to the questionnaires that aim to detect symptoms of CMD and not to establish a formal diagnosis. For this reason, further longitudinal studies including a qualitative stage with psychiatric interview are required for a more accurate definition of the problem outcome found in our study. Despite these limitations, the study suggests hypotheses and supplies important data for preventive measures to be adopted.

\section{Conclusion}

Considering all the above, it is evident that the mental health of those who will soon become healthcare suppliers for the population needs more attention.

There was no difference regarding CMD prevalence among the students of medicine, dentistry and nursing in the university surveyed. This population showed a high prevalence of CMD and more than its half was discontent with the teaching strategies adopted, having thought at least once about dropping out the course. Furthermore, the majority considered the course chosen as a source of pleasure and had good expectations for the future.

The high prevalence of common mental disorder found by the researchers suggests that preventive measures must be immediately implemented such as: psychopedagogical support services for students and lecturers, development courses for the teaching staff, and a healthier environment to improve interpersonal relationships. In addition, we also suggest the raising of awareness among future healthcare professionals regarding the importance of maintaining their physical and mental wellbeing, which impact positively in the patient assistance.

Longitudinal studies assessing this theme at the researched university and other universities that have a population with similar profile are necessary aiming to identify the causal factors of common mental disorder among students from health-related courses.

\section{Resumo}

Transtornos mentais comuns e fatores associados entre estudantes de saúde do último ano.

Objetivo: determinar a prevalência de transtorno mental comum (TMC) e identificar potenciais fatores associados entre estudantes de medicina, odontologia e enfermagem. 
Métodos: estudo transversal realizado em uma universidade pública no Nordeste do Brasil com 172 alunos de graduação dos últimos três semestres de Medicina, Odontologia e Enfermagem, em fevereiro de 2010, utilizando o Self Reporting Questionnaire (SRQ-20) e um questionário estruturado desenvolvido pelos autores. A análise dos dados foi realizada por regressão logística.

Resultados: a prevalência de TMC foi de $33,7 \%$. Os cursos não apresentaram diferenças na prevalência de TMC. A regressão logística mostrou uma forte associação entre as seguintes variáveis com TMC: sexo feminino $(\mathrm{OR}=4,34)$, não ter boas expectativas em relação ao futuro $(\mathrm{OR}=5,83)$, curso não ser uma fonte de prazer $(\mathrm{OR}=7,52)$ e sentir-se emocionalmente tenso $(\mathrm{OR}=11,23)$.

Conclusão: a alta prevalência de TMC sugere que medidas preventivas imediatas devam ser implementadas, como: a criação de serviços de apoio psicopedagógico para alunos e programas de desenvolvimento docente.

Palavras-chave: saúde mental, estudantes de odontologia, saúde do trabalhador, estudantes de medicina, estudantes de enfermagem, transtornos mentais.

\section{REFERENCES}

1. Mari JJ, Williams P. A validity study of a psychiatric screening questionnaire (SRQ20 ) in primary care in the city of Sao Paulo. Br J Psychiatry. 1986;148:23-6.

2. Goldberg DP, Huxley P. Common mental disorders a bio-social model. London: Tavistock/Routledge; 1992

3. Birks Y, McKendree J, Watt I. Emotional intelligence and perceived stress in healthcare students: a multi-institutional, multi-professional survey. BMC Med Educ. 2009;9(1):61.

4. Harding TW, de Arango MV, Baltazar J, Climent CE, Ibrahim HH, LadridoIgnacio L, et al. Mental disorders in primary health care: a study of their frequency and diagnosis in four developing countries. Psychol Med. 1980;10(2):231-41.

5. Meleiro AM. [Suicide among physicians and medical students]. Rev Assoc Med Bras. 1998;44(2):135-40.

6. Benjakul $\mathrm{P}$, Cheunarrom C. Student adjustment problems in two dental schools in Thailand. J Dent Educ. 2000;64(5):365-9.

7. Burnard P, Haji Abd Rahim HT, Hayes D, Edwards D. A descriptive study of Bruneian student nurses perceptions of stress. Nurse Educ Today. 2007;27(7):808-18.

8. Facundes VL, Ludermir AB. Common mental disorders among health care students. Rev Bras Psiquiatr 2005;27(3):194-200.

9. Gorter R, Freeman R, Hammen S, Murtomaa H, Blinkhorn A, Humphris G. Psychological stress and health in undergraduate dental students: fifth year outcomes compared with first year baseline results from five European dental schools. Eur J Dent Educ. 2008;12(2):61-8.

10. Heath JR, Macfarlane TV, Umar MS. Perceived sources of stress in dental students. Dent Update. 1999;26(3):94-8,100.

11. Tyssen R, Vaglum P, Gronvold NT, Ekeberg O. Factors in medical school that predict postgraduate mental health problems in need of treatment. A nationwide and longitudinal study. Med Educ. 2001;35(2):110-20.

12. Lima MS, Beria JU, Tomasi E, Conceição AT, Mari JJ. Stressful life events and minor psychiatric disorders: an estimate of the population attributable fraction in a Brazilian community-based study. Int J Psychiatr Med. 1996;26(2):211-22.
13. Ludermir AB, Melo Filho DA. [Living conditions and occupational organization associated with common mental disorders]. Rev Saúde Pública. 2002;36(2):213-21.

14. Costa EF, Andrade TM, Silvany Neto AM, Melo EV, Rosa AC, Alencar MA, et al. Common mental disorders among medical students at Universidade Federal de Sergipe: a cross-sectional study. Rev Bras Psiquiatr. 2010;32(1):11-9.

15. Divaris K, Barlow PJ, Chendea SA, Cheong WS, Dounis A, Dragan IF, et al. The academic environment: the students perspective. Eur J Dent Educ 2008;12(Suppl 1):120-30

16. Lloyd C, Musser LA. Psychiatric symptoms in dental students. J Nerv Ment Dis. $1989 ; 177(2): 61-9$

17. Seyedfatemi N, Tafreshi M, Hagani H. Experienced stressors and coping strategies among Iranian nursing students. BMC Nurs. 2007;6:11.

18. Wexler M. Mental health and dental education. J Dent Educ. 1978;42(2):74-7.

19. Lima MC, Domingues MS, Cerqueira AT. [Prevalence and risk factors of common mental disorders among medical students]. Rev Saúde Pública. 2006;40(6):1035-41.

20. Almeida AM, Godinho TM, Bitencourt AGV, Telles MS, Silva AS, Fonseca DC, et al. Common mental disorders among medical students. J Bras Psiquiatr. 2007;56(4):245-51.

21. Benvengnú LA, Deitos F, Copette FR. Problemas psiquiátricos menores em estudantes de medicina da Universidade Federal de Santa Maria, RS. Rev Psiquiatr Rio Gde Sul. 1996;18(3):229-233

22. Marin-Leon L, Oliveira HB, Barros MB, Dalgalarrondo B, Botega NJ. Socia inequality and common mental disorders. Rev Bras Psiquiatr. 2007;29(3):250-3.

23. Omigbodun OO, Odukogbe AT, Omigbodun AO, Yusuf OB, Bell TT, Olayem $\mathrm{O}$, et al. Stressors and psychological symptoms in students of medicine and allied health professions in Nigeria. Soc Psychiatry Psychiatr Epidemiol 2006;41(5):415-21.

24. Rodrigues-Neto JF, Figueiredo MFS, Faria AAS, Fagundes M. Transtornos mentais comuns e o uso de práticas de medicina complementar e alternativa: estudo de base populacional. J Bras Psiquiatr. 2008;57(4):233-9.

25. Shariati M, Yunesian M, Vash JH. Mental health of medical students: a crosssectional study in Tehran. Psychol Rep. 2007;100(2):346-54.

26. Kaya M, Genc M, Kaya B, Pehlivan E. [Prevalence of depressive symptoms, ways of coping, and related factors among medical school and health services higher education students]. Turk Psikiyatri Derg. 2007;18(2):137-46.

27. Compton MT, Carrera J, Frank E. Stress and depressive symptoms/dysphoria among US medical students: results from a large, nationally representative survey. J Nerv Ment Dis. 2008;196(12):891-7.

28. Millan LR, Arruda PC. [Psychological assistance to medical students: 21 years of experience]. Rev Assoc Med Bras. 2008;54(1):90-4.

29. Finger G, Silva ER, Falavigna A. Use of methylphenidate among medical students: a systematic review. Rev Assoc Med Bras. 2013;59(3):285-9.

30. Gaultney JF. The prevalence of sleep disorders in college students: impact on academic performance. J Am Coll Health. 2010;59(2):91-7.

31. Costa EF, Santana YS, Santos AT, Martins LA, Melo EV, Andrade TM. [Depressive symptoms among medical intern students in a Brazilian public university]. Rev Assoc Med Bras. 2012;58(1):53-9.

32. Leao PB, Martins LA, Menezes PR, Bellodi PL. Well-being and help-seeking: an exploratory study among final-year medical students. Rev Assoc Med Bras. 2011;57(4):379-86.

33. Dusselier L, Dunn B, Wang Y, Shelley MC $2^{\text {nd }}$, Whalen DF, et al. Personal, health, academic, and environmental predictors of stress for residence hall students. J Am Coll Health. 2005;54(1):15-24

34. Baldassin S, Silva N, de Toledo Ferraz Alves TC, Castaldelli-Maia JM, Bhugra D, Nogueira-Martins MC, et al. Depression in medical students: Cluster symptoms and management. J Affect Disord. 2012;150(1):110-4

35. Costa EF, Santos SA, Santos AT, Melo EV, Andrade TM. Burnout syndrome and associated factors among medical students: a cross-sectional study. Clinics. 2012;67(6):573-80

36. De Abreu Santos AT, Grosseman S, de Oliva Costa EF, da Andrade TM. Burnout syndrome among internship medical students. Med Educ. 2011;45(11):1146.

37. Roh MS, Jeon HJ, Kim H, et al. Factors influencing treatment for depression among medical students: a nationwide sample in South Korea. Med Educ. 2009;43(2):133-9.

38. Kraft DP. One hundred years of college mental health. J Am Coll Health. 2011;59(6):477481. 